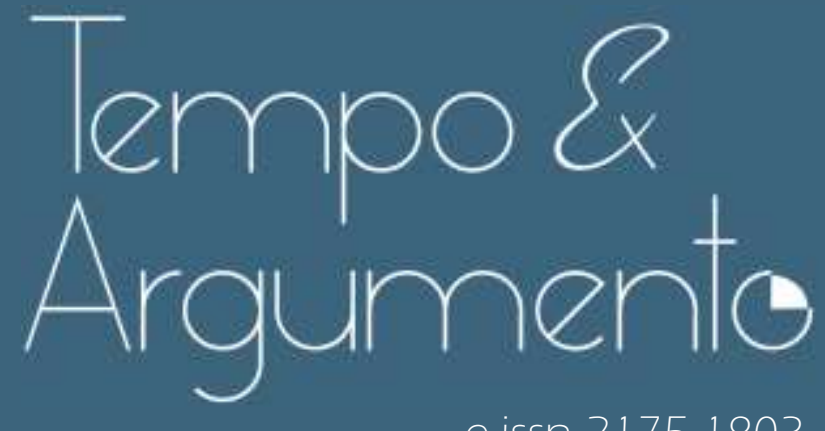

e-issn 2175-1803

\title{
História e memória do teatro pernambucano: a genealogia de uma memória coletiva
}

- Idelmar Gomes Cavalcante Júnior

Doutor em História pela Universidade Federal do Ceará (UFC).

Professor da Universidade Estadual do Piauí (UESPI).

Parnaíba, PI - BRASIL

lattes.cnpq.br/4333255540626521

idelmargomes@phb.uespi.br

(D) orcid.org/0000-0003-4621-7806

Para citar este artigo:

CAVALCANTE JÚNIOR, Idelmar Gomes. História e memória do teatro pernambucano: a genealogia de uma memória coletiva. Tempo e Argumento, Florianópolis, v. 13, n. 34, e0303, set./dez. 2021.

do) http://dx.doi.org/10.5965/2175180313342021e0303

Recebido: 07/07/2020

Aprovado: 30/05/2021 


\title{
História e memória do teatro pernambucano: a genealogia de uma memória coletiva ${ }^{1}$
}

\begin{abstract}
Resumo
Neste artigo, analisamos a constituição de uma memória coletiva a partir da contribuição de obras consagradas como fundamentais para a compreensão da trajetória do teatro pernambucano. As obras selecionadas foram: O teatro moderno em Pernambuco, de Joel Pontes; O teatro em Pernambuco, de Alexandre Figueirôa; Por um teatro do povo e da terra, de Luís Maurício Carvalheira e TAP - sua cena e sua sombra, de Antonio Cadengue. Com a análise desses textos, procuramos mostrar de que forma algumas teses sobre o teatro pernambucano foram se consolidando pela regularidade com que foram enunciadas ao longo de cinco décadas. Essas teses foram enquadradas numa narrativa consagrada, através da qual diferentes sujeitos e grupos de teatro foram nomeados e desafiados a comprovarem uma função específica na memória organizadora constituída por essa narrativa, sob pena de caírem no esquecimento por falta de relevância. Neste sentido, a constituição de uma memória coletiva, como estudamos aqui, não tem como tema principal uma correspondência entre os discursos analisados e o "real", mas a coerência interna de uma narrativa consagrada e suas ideias sobre o teatro pernambucano.
\end{abstract}

Palavras-chave: história; memória; teatro pernambucano; genealogia.

\section{History and memory the theater of pernambuco: the genealogy of a collective memory}

\begin{abstract}
In this article, we look at the Constitution of a collective memory from the contribution of works consecrated as fundamental to understanding the trajectory of the theater. The works selected were: The modern theater in Pernambuco, by Joel Pontes; The theater in Pernambuco, by Alexandre Figueirôa; For a theater of the people and of the Earth, of Luís Maurício Carvalheira and TAP-your scene and your shadow, by Antonio Cadengue. With the analysis of these texts, we try to show how some theses on the theater of Pernambuco were consolidated by the regularity with which have been set out over five decades. These theses were framed in a narrative, through which different subjects and theater groups were named and challenged to prove a particular role in organizing memory consists of this narrative, under pain of falling into Oblivion for lack of relevance. In this sense, the constitution of a collective memory, as we have studied here, does not have as its main theme a correspondence between the discourses analyzed and the "real", but the internal coherence of a consecrated narrative and its ideas about the Pernambuco theater.
\end{abstract}

Keywords: history; memory; theatre of Pernambuco; genealogy.

\footnotetext{
Este artigo é derivado da tese de doutorado deste autor, intitulada "Inventário de uma memória consagrada: Benjamim Santos nos interstícios do teatro pernambucano (1960-1970)".
} 
O que é o teatro pernambucano? Um teatro feito em Pernambuco ou aquele que expressa particularidades daquele estado, incorporando traços identitários? Ao que tudo indica, a maioria das narrativas que contam a sua história parece legitimar um teatro expressivo da pernambucanidade², o que em Pernambuco, significa também dizer expressivo de um teatro nordestino.

Toda demanda identitária, normalmente, acaba buscando soluções a partir da memória. Isso porque se uma identidade pressupõe a permanência de um ser que continuaria igual a si mesmo diante da passagem do tempo, a memória pode oferecer a ilusão de uma identidade fixa apesar dos efeitos desse tempo, já que, por meio dela, "o que passou não está definitivamente inacessível, pois é possível fazê-lo reviver graças à lembrança. Pela retrospecção o homem aprende a suportar a duração: juntando os pedaços do que foi numa nova imagem que poderá talvez ajudá-lo a encarar sua vida presente" (CANDAU, 2012, p. 15). Nesta perspectiva, a memória poderia funcionar como fonte para a identidade, tanto individual, quanto coletiva, como atesta Joël Candau (CANDAU, 2012, p. 16-17).

Assim, como para qualquer identidade coletiva, a existência de uma identidade historicamente fixada para o teatro pernambucano estaria diretamente ligada à capacidade das memórias individuais se articularem em torno de uma memória, neste caso, uma memória organizadora ${ }^{3}$ E ainda segundo a orientação de Candau: “se a memória é 'geradora' de identidade, no sentido que participa de sua construção, essa identidade, por outro lado, molda predisposições que vão levar os indivíduos a 'incorporar' certos aspectos particulares do passado, a fazer escolhas memoriais" que dependerão da

\footnotetext{
${ }^{2}$ De tão aparelhada, a identidade pernambucana recebe um nome próprio: "Pernambucanidade". Segundo Nilo Pereira, o termo tornou-se conhecido por causa de Gilberto Freyre (PEREIRA, 1983). Essa Pernambucanidade é fortemente marcada por alguns acontecimentos que se tornaram fatos cristalizados na história de Pernambuco, especialmente, aqueles dos quais se pode extrair traços de heroísmo, liberalismo, vocação libertária e de uma defesa intransigente da unidade regional e nacional. Mas a Pernambucanidade, apesar de seu caráter progressista, também sabe conservar tradições. Por isso a Batalha dos Guararapes tornou-se um marco fundador para essa identidade pernambucana fortemente instrumentalizada. Com ela, os pernambucanos puderam desenvolver a consciência de que a unidade de um Brasil "lusocatólico" (ameaçada pelos holandeses calvinistas) só foi possível graças a sua intervenção direta.

Para Joël Candau, uma memória organizadora dá suporte para a memória coletiva e faz isso oferecendo às memórias individuais, uma narrativa consagrada que thes dê um sentido, uma orientação. Trata-se de uma memória importante para a estruturação de um grupo e, particularmente, para a representação que ele vai ter de sua própria identidade (CANDAU, 2012, p. 44).
} 
representação que eles fazem de suas próprias identidades (CANDAU, 2012, p. 19). Ou seja, para a análise de uma demanda identitária como a configuração de um "teatro pernambucano", deveríamos estar atentos ao fato de que a identidade depende da memória e vice-versa.

Desta forma, a memória, normalmente modeladora de uma identidade, poderia também ser modelada pela identidade. Restaria, então, a questão a respeito de a quem caberia executar as "escolhas memoriais" e, sobretudo, quais seriam os limites e possibilidades para se pensar identidades e memória coletivas.

Para alguns estudiosos, a ideia de uma identidade cultural ou coletiva é uma impossibilidade se estiver se referindo a grupos em sua totalidade. Da mesma forma, é possível encontrar quem identifique na ideia de "memória coletiva" algo bastante problemático, como atesta Joël Candau:

Idealmente, a metáfora "memória coletiva" aplicada a um determinado grupo seria totalmente pertinente se todos os membros do grupo fossem capazes de compartilhar integralmente um número determinado de representações relativas ao passado que thes teriam sido previamente comunicadas de acordo com as modalidades variáveis, mas socialmente determinadas e culturalmente regradas [...]. Entretanto, é difícil aceitar essa ideia, pois de um lado ela é empiricamente impossível e de outro é insustentável sob o ponto de vista teórico, já que encobre uma tripla confusão: a primeira, entre as lembranças manifestadas (objetivadas) e as lembranças tais como são memorizadas; a segunda, entre a metamemória ${ }^{4}$ e a memória coletiva; e a última, entre o ato de memória ${ }^{5}$ e 0 conteúdo desse ato. (CANDAU, 2012, p. 31-32)

Para o estudioso, não existiria um compartilhamento natural de lembranças. Mesmo se referindo a um mesmo acontecimento, indivíduos evocariam suas lembranças de forma diferente uns dos outros "levando em consideração as escolhas que cada cérebro pode fazer no grande número de combinações da totalidade de sequências" (CANDAU, 2012, p. 36). "Memórias

\footnotetext{
${ }^{4}$ A metamemória é uma representação criada para a faculdade da memória. É o conhecimento que um indivíduo tem de sua própria memória e o que diz dela. "A metamemória é, portanto, uma memória reivindicada, ostensiva" (CANDAU, 2012, p. 23).

${ }^{5}$ Ato de memória é a memória apresentada como um fato, no caso, o fato de se lembrar, que pode se manifestar nas comemorações, construção de museus, narrativas... (CANDAU, 2012, p. 35).
} 
compartilhadas", portanto, seriam somente uma metáfora que se manifestaria em nomes como "memória coletiva" ou "memória familiar", conclui Candau. Por essa razão, ele admite a memória coletiva como uma representação, "uma forma de metamemória, quer dizer, um enunciado que membros de um grupo vão produzir a respeito de uma memória supostamente comum a todos os membros desse grupo" (CANDAU, 2012, p. 24).

Portanto, para analisar a construção de uma memória consagrada para o teatro de Pernambuco, pensamos esse teatro como um objeto dotado de identidade nomeada e não como um objeto portador de uma essência. Sua identidade foi construída ao longo do tempo como uma representação diretamente relacionada a uma memória organizadora transmitida não só pela oralidade, mas, sobretudo, a partir de textos que hoje podem ser considerados normativos.

Dito isso, passemos então para a análise da constituição da narrativa consagrada que garante a materialidade dessa memória organizadora e de como o teatro pernambucano dos anos sessenta foi inserido numa memória coletiva que se impôs sobre outras possíveis nos últimos cinquenta anos.

Neste caso, identificamos práticas discursivas que, ao longo do tempo, foram convergindo para uma narrativa única, consagrada, sem que isso tivesse sido colocado de forma mecânica, atendendo a uma destinação particular. Pensamos genealogicamente a criação da memória organizadora. Ela não tem origem, ela tem começo, um estado de formigamento inicial, quando sua pretensa essência começa a ser "construída peça por peça a partir de figuras que lhe eram estranhas" (FOUCAULT, 2015, p. 58). Sua emergência acontece como toda emergência na história: com a entrada em cena de forças que lutam umas contra as outras, inclusive contra si mesmas, que se cumpre no acaso de uma luta, sem projetos. "Ninguém é, portanto, responsável por uma emergência; ninguém pode se autoglorificar por ela; ela sempre se produz no interstício" (FOUCAULT, 2015, p. 67-68).

Acontecimentos dispersos deram-lhe forma como em um acidente e não como um projeto em execução. O que não quer dizer que não possamos identificar alguns protagonistas desses acontecimentos ou, para citar um termo 
de Joël Candau, os responsáveis por algumas das "escolhas memoriais" que historicamente se consagraram. Esses acontecimentos se tornaram mais evidentes a partir da própria década de sessenta, com o lançamento do livro 0 teatro moderno em Pernambuco, de Joel Pontes. Na década seguinte, anos setenta, um momento novo da cena pernambucana, não foi publicada nenhuma obra que tratasse da memória ou da história do teatro pernambucano. Só nos anos oitenta uma nova publicação seria lançada: Por um teatro do povo e da terra, de Luís Maurício Carvalheira, que trata das trajetórias do Teatro do Estudante de Pernambuco e de Hermilo Borba Filho.

Essas duas publicações acabaram definindo não apenas um recorte temporal consagrado para a compreensão da história do teatro pernambucano, mas também o que seria a sua "correta leitura” contra eventuais distrações. Neste sentido, a história a ser contada só avança até o início dos anos sessenta, um limite no qual se acomodaria um teatro que agradava a elite intelectual e econômica da sociedade pernambucana. Um teatro com o qual ela se identificava. Essas duas obras, sobretudo a de Joel Pontes, se constituíram como referências importantes de uma narrativa consagrada que vem sendo permanentemente atualizada nos últimos cinquenta anos por meio de sucessivas publicações, seminários e cursos sobre teatro.

Façamos agora algumas considerações sobre a relação entre história e memória que ao longo do tempo foi, por importantes teóricos, determinada pelo signo da oposição. Segundo Aleida Assmann, "uma é sempre o que a outra não é. Assim, tanto se descreveu o surgimento da historiografia crítica como emancipação em relação a uma memória oficial quanto se fez prevalecerem os direitos da memória em face de uma ciência histórica poderosa demais" (ASSMANN, 2011, p. 143).

Mas Assmann não concorda com tal oposição e, embora entenda que seria também um equívoco equiparar plenamente os dois conceitos, apoia a ideia de que qualquer escrita da história é também trabalho de memória. Por essa razão, prefere compreender a história e a memória como dois modos da recordação "que não precisam excluir-se nem recalcar-se mutuamente" (ASSMANN, 2011, p. 147). Segundo a autora: 
Gostaria de afastar o problema desse contexto e perguntar de que maneira esses conceitos podem ser referidos um ao outro de modo produtivo e voltar a tornar-se utilizáveis do ponto de vista analítico.

O passo essencial para além da polarização ou equiparação dos conceitos de memória e história consiste em compreender a relação entre memória habitada e inabitada no sentido de dois modos complementares da recordação. Denominaremos a memória habitada memória funcional. Suas características mais marcantes são referência ao grupo, à seletividade, à vinculação a valores e à orientação para o futuro. As ciências históricas, por sua vez, são uma memória de segunda ordem, uma memória das memórias, que acolhe em si aquilo que perdeu a relação vital com - presente. Sugiro atribuir a essa memória das memórias a designação memória cumulativa. (ASSMANN, 2011, p. 147)

É nessa perspectiva, que pensa a história e a memória como "dois modos complementares da recordação", que decidimos pensar a construção da memória a partir de uma economia escriturística, como metodologia para descortinar a emergência de uma memória organizadora que fundamentou as recordações a respeito do teatro em Pernambuco na década de sessenta. Isso porque sendo a economia escriturística uma prática baseada em um conhecimento erudito que, por sua disciplina e objetividade, constrange os homens ordinários dotados de saberes e tradições baseadas na oralidade (CERTEAU, 1994, p. 222), acreditamos que ela é muito útil para representar a consagração de um determinado saber.

Neste sentido, levando em consideração que essa memória organizadora se confunde com uma narrativa consagrada, decidimos selecionar do conjunto das obras que abordam a história do teatro em Pernambuco, apenas quatro: 0 teatro moderno em Pernambuco, de Joel Pontes; O teatro em Pernambuco, de Alexandre Figueirôa; Por um teatro do povo e da terra, de Luís Maurício Carvalheira e TAP - sua cena e sua sombra, de Antonio Cadengue.

Inicialmente, levamos em conta dois critérios para a nossa seleção: a obra deveria tratar da história do teatro pernambucano e não de temas específicos vinculados a ele e gozar de boa visibilidade. Nesse caso, apenas as obras de Joel Pontes, de Alexandre Figueirôa e, de certa forma, a de Antonio Cadengue, que embora prestigie o Teatro de Amadores de Pernambuco (TAP), oferece um panorama amplo do teatro pernambucano nos anos sessenta, atenderiam ao 
critério. Posteriormente, pela recorrência com que a obra de Luís Maurício Carvalheira é citada em pesquisas e depoimentos analisados, o que comprova a sua influência, decidimos incluí-la em nosso estudo.

\section{O teatro moderno em Pernambuco}

Em 1966, o teatro em Pernambuco vivia um momento de transição. O Teatro de Amadores estava em clima de comemoração pelos seus 25 anos de existência e buscava reafirmar o valor do grupo perante a sociedade pernambucana num momento em que não conseguia mais surpreender com suas montagens; a "dramaturgia nordestina" produzida em Pernambuco se encontrava em suspensão, sem que novas peças despontassem, mantendo o seu prestígio por meio daquelas que já eram consagradas; a televisão conquistava cada vez mais audiência e se tornava um forte concorrente para as artes cênicas; surgiam os primeiros ídolos ligados à cultura de massa no Brasil, como Chico Buarque, que conquistara a primeira colocação no festival da Record daquele ano, com a música $A$ banda; crescia o interesse pela arte de vanguarda e a ousadia começava a subir aos palcos, às vezes sofrendo forte oposição das autoridades, como o que aconteceu com o espetáculo Les girls em op art, show de travestis que foi proibido de se apresentar no tradicional teatro de Santa Isabel e, finalmente, ressurgia o Teatro Popular do Nordeste.

Foi neste contexto que Joel Pontes lançou o seu livro O teatro moderno em Pernambuco. O texto veio atender à necessidade de reafirmação dos valores do "teatro pernambucano", num momento em que a sua pretensa identidade começava a se diluir diante de uma cultura de massa emergente; diante do que parecia ser o esgotamento da "dramaturgia nordestina" feita no estado e diante da experiência de novos e impertinentes protagonistas, que não prestavam homenagens ao passado. Mas o texto veio também atender à necessidade, ainda em alta desde a década de 1920, de se proceder um novo "descobrimento do Brasil" a partir de suas diversas regiões ${ }^{6}$.

\footnotetext{
" Sobre isso, Durval Muniz fala no "dispositivo das nacionalidades" que entre os anos de 1920 e 1960, no Brasil, "impunha aos homens a necessidade de ter uma nação" (ALBUQUERQUE JÚNIOR, 2001, p. 48). Neste período, é possível destacar na década de 1920 os investimentos do
} 
Segundo seus editores, a obra seria o primeiro de uma série de três volumes dedicada à história do teatro moderno no Brasil. Os outros dois seriam dedicados a São Paulo e ao Rio de Janeiro, "partindo da premissa de que num país tão extenso e de vida cultural tão fragmentária como o nosso, não se poderia chegar a uma visão de conjunto a não ser através de estudos regionais feitos por especialistas", como está escrito na apresentação.

A obra também pode ser considerada o primeiro investimento para a construção de uma representação historiográfica do que começava, na época, a ser considerado o moderno teatro pernambucano. Com sua publicação ganha força uma tradição narrativa, que se não é iniciada por Joel Pontes, certamente, ganha com ele a sua principal referência. O autor instituiu recortes muito precisos para a sua narrativa e, com eles, um sentido para a modernização do teatro pernambucano. Sua narrativa vai “de 1930 para cá, do Grupo Gente Nossa ao Teatro de Amadores de Pernambuco [TAP], do Teatro do Estudante de Pernambuco [TEP] ao Teatro Popular do Nordeste [TPN]". E entre os protagonistas, ganham destaque Samuel Campelo (fundador do Gente Nossa), Valdemar de Oliveira (fundador do TAP), Ariano Suassuna (autor da festejada Auto da compadecida) e Hermilo Borba Filho (fundador do TEP e do TPN), todos citados como "nomes de longa projeção nacional”. Depois disso, raramente uma narrativa que se propõe a falar sobre a história do teatro em Pernambuco deixa de trabalhar com esses mesmos elementos constituintes.

A credibilidade de seu texto estava triplamente assegurada. Primeiro porque Joel Pontes já era conhecido como um influente crítico teatral, com espaço garantido no tradicional Diário de Pernambuco. Segundo, por um capital científico reconhecido, já que ele era também ensaísta e professor universitário. E terceiro, porque, embora rejeitasse a ideia de que tivesse se fundamentado também em suas próprias memórias, ele acompanhou de perto boa parte daquilo que narra, afinal já havia trabalhado nos três grupos de maior repercussão em Pernambuco: Trabalhou no TEP, no qual ingressou em 1946; no

Modernismo paulista e do Movimento Regionalista no Nordeste, ambos pensando a nação brasileira a partir da generalização das características e potencialidades de suas próprias regiões de origem. O Modernismo exaltando as mudanças, a velocidade e o futuro; e o Regionalismo, as tradições, o ritmo lento das antigas Casas-Grandes e o passado. 
TAP, por dois anos (1958 e 1959) e no TPN, onde permaneceu também por dois anos (1960 e 1961).

O texto de Joel Pontes, com o tempo, ocupará um lugar central na história e memória do teatro de Pernambuco e, com ele, também uma trajetória exemplar que vai do grupo Gente Nossa ao TPN em sua primeira fase (1960-1963), passando evidentemente pelo TEP; grupos, segundo o autor, responsáveis pelo surgimento de uma dramaturgia pernambucana, considerada um elemento importante para a cultura nordestina. O TAP, que merece grande visibilidade na sua obra, também tem o seu valor reconhecido na história da modernização teatral em Pernambuco, mas as críticas que Joel Pontes faz às opções estéticas adotadas pelo grupo, que possuía uma clara preferência por uma dramaturgia estrangeira, atestam que o autor defendia não apenas avanços do ponto de vista técnico, mas, sobretudo, comprometimento com questões identitárias.

Neste caso, ele defende que o moderno teatro pernambucano estava se encaminhando para o regionalismo. Joel Pontes afirma que o desenvolvimento do teatro brasileiro moderno, no que cabe a Pernambuco, "é um assunto que só adquire grandeza ante a observação dos estudiosos se for entendido como uma procura, tantas vezes heroica, das soluções e caminhos adequados às circunstâncias regionais" (PONTES, 1966, p. 1). Para ele, o compromisso com "temas nordestinos", antes de ser uma reação política ao descaso dos centros decisórios do país voltado para a região Nordeste, deve se justificar como algo que faria parte da própria natureza do ser nordestino, como um compromisso com a própria existência: "Cabe aos nordestinos, com primazia e legitimidade, o aproveitamento dos valores telúricos circundantes que, sobretudo nos escritores nascidos nas zonas rurais, fazem parte íntima de suas próprias existências" (PONTES, 1966, p. 6-7).

Segundo Joel Pontes, essa crescente valorização da dramaturgia regional desencadeou, em consequência, várias atividades conexas ao teatro, como edições de peças, publicações, comemorações locais e campanhas filantrópicas (PONTES, 1966, p. 7). O autor, no entanto, não atribui a essa circunstância uma relação de poder. Não relaciona esse espaço conquistado pelo ser regional a uma tradição intelectual em Pernambuco profundamente identificada com o 
regionalismo nordestino, que tem forte influência na grande mídia e nas instituições de fomento cultural, e descreve o que acontece apenas como uma “adaptação ao meio” (PONTES, 1966, p. 7).

Assim, o discurso de Joel Pontes naturaliza a adoção do regionalismo nordestino pelo teatro de Pernambuco e se alinha a uma regularidade discursiva que naquele estado une diferentes gerações de intelectuais e artistas, não apenas em torno da necessidade de se retratar o Nordeste por meio de sua gente e de sua cultura, mas também em torno da ideia de que Pernambuco é o centro da região nordestina e que a esse estado estaria destinada uma ação civilizatória; ideias antigas e notórias desde o surgimento do Instituto Arqueológico e Geográfico Pernambucano e os primeiros anos da Faculdade de Direito do Recife.

O teatro moderno em Pernambuco também opera uma prática discursiva responsável pela naturalização do sucesso de alguns grupos teatrais em detrimento de outros. Sua história do teatro pernambucano vai ao passado para encontrar algo familiar ao presente, se limitando a revisitar a trajetória dos grupos que, nos anos sessenta, Joel Pontes já sabia serem "vitoriosos". A história narrada não é um espaço de contingências ou contradições; é uma trama de cartas marcadas, na qual todos já conhecem o final, pois ele foi justamente o ponto de partida. Isso porque a história moderna, como Michel de Certeau nos diz, “trabalha para encontrar um presente que é o término de um percurso, mais ou menos longo, na trajetória cronológica [...] o presente, postulado do discurso, torna-se a renda da operação escriturária: o lugar de produção do texto se transforma em lugar produzido pelo texto" (CERTEAU, 2011, p. 95-96).

Por isso, embora reconheça que seu trabalho não é um estudo completo, Joel Pontes acredita que ampliar o foco de suas análises o levaria a se perder em "minudências" e assim "escapariam as linhas gerais que unem 1931 aos dias de hoje, numa sucessão lógica de transformações” (PONTES, 1966, p. 8). Propõese, então, a narrar uma história que deu certo, em um desenvolvimento linear dentro do qual continuaremos ignorando projetos que não foram adiante, os quais são considerados ora como "companhias que nada acrescentam ao acervo cultural do Estado" (PONTES, 1966, p. 5), ora como iniciativas heroicas pelas 
dificuldades que enfrentaram e "nada mais do que isso" (PONTES, 1966, p. 42). Neste último caso, referindo-se ao teatro no interior do Estado.

Joel Pontes chega a falar brevemente de alguns grupos cujas experiências são consideradas, por ele, uma espécie de "parênteses" (PONTES, 1966, p. 53). Eles estão situados justamente entre o capítulo que fala do TAP e aquele que fala do TEP, e levando em consideração que gramaticalmente parênteses introduzem em um texto, de forma intercalada, uma informação adicional que não chega a ser essencial para a compreensão do todo, podemos concluir que o essencial para Joel Pontes é narrar a história de alguns grupos, notadamente o Gente Nossa, o TAP, TEP e o TPN (na sua primeira fase), e que a história do teatro moderno em Pernambuco pode prescindir de outras experiências, consideradas menores. "Assim, só nos convém lembrar aqueles que se distinguem por algum relevo ou que possam oferecer sugestões fecundas a entidades semelhantes" (PONTES, 1966, p. 123).

O Teatro Universitário de Pernambuco (TUP) foi um grupo que mereceu um certo destaque na obra. No entanto, embora Joel Pontes reconheça suas qualidades e vitórias, especialmente suas excelentes colocações nos Festivais Nacionais de Teatros do Estudante, o grupo não escapa das comparações que são feitas para que ele se torne familiar aos leitores. Como se fosse possível pensar o teatro apenas a partir de grandes marcos, primeiro ele é apresentado como uma negação ao TEP, inspirado que foi por um fascínio pelo TAP, com "suas montagens, seus diretores contratados, sua projeção na sociedade" (PONTES, 1966, p. 58). Depois, Joel Pontes observa com simpatia que o TUP acabou se afastando de suas diretrizes iniciais (o exemplo do TAP), adotando algumas características do Teatro do Estudante, com o seu regionalismo e valorização da cultura popular (PONTES, 1966, p. 60-61).

Por essa pauta identitária, Joel Pontes provavelmente tenha sido bastante influenciado pelo livro O Teatro no Brasil, de J. Galante de Sousa, apontado como “fonte de consulta” em seu estudo. Para Rosângela Patriota e J. Guinsburg, a ideia dessa obra, uma das primeiras a influenciarem a construção de uma historiografia para o teatro brasileiro, é justamente o tema nacional como 
aglutinador dos esforços empreendidos para a criação de uma cena teatral brasileira. (GUINSBURG; PATRIOTA, 2012, p. 67).

É justamente esse o critério que orienta os recortes feitos por Joel Pontes. Ele institui a história do teatro moderno em Pernambuco tendo em vista aquilo que entende ser a maior contribuição dos grupos cênicos pernambucanos para o teatro brasileiro moderno: a formação de uma "dramaturgia sempre renovada e, sob os aspectos de conteúdo e linguagem regional, autóctone" (PONTES, 1966, p. 5-6). A partir daí, ele opera a sua classificação, definindo a origem da dramaturgia pernambucana (com o grupo Gente Nossa), o grupo que inovou tecnicamente o teatro local (O TAP), o teatro propriamente regionalista (O TEP) e o herdeiro do TEP (TPN).

No capítulo “Fundação do 'Grupo gente Nossa”, o autor já demonstra o sentido histórico da sua narrativa logo nas primeiras linhas, ao afirmar que "lançando um olhar retrospectivo sobre o teatro pernambucano, não encontramos qualquer afinidade entre os acontecimentos de hoje e os anteriores a 1931" (PONTES, 1966, p. 10). Ele, portanto, demarca claramente uma origem para o "teatro moderno em Pernambuco". Tudo teria se iniciado com a fundação do grupo Gente Nossa, em 1931, e o que se observaria depois seria marcado por uma evolução contínua que qualificaria os trinta anos seguintes como familiares ao presente do autor (os anos de 1960), um tempo contínuo caracterizado como um "desde sempre": "Desde sempre os pernambucanos vêm se preocupando com isso, contratando profissionais (desde o Grupo Gente Nossa)" (PONTES, 1966, p. 3).

Se tomarmos o tempo como uma construção social que determina a relação entre as experiências e as expectativas de uma sociedade numa determinada época, operar tal ideia de continuidade só seria possível em um contexto em que as experiências dos homens desse período e suas expectativas pudessem se encontrar sem sobressaltos (KOSELLECK, 2006).

Nesses termos, poderíamos afirmar que, ao escrever seu livro, Joel Pontes: 1) teria ainda as mesmas expectativas ou expectativas muito próximas daqueles que experimentaram o teatro pernambucano nos anos trinta e quarenta, 2) estaria negando uma mudança significativa neste teatro entre os anos trinta e os 
anos sessenta ou 3) estaria vivendo essas duas condições ao mesmo tempo. As três opções são problemáticas para quem trabalha com a história.

E se o Gente Nossa é a origem, tendo sido o responsável pelo surgimento da dramaturgia pernambucana (PONTES, 1966, p. 36), coube ao TAP superar a sua falta de refinamento social e técnico. Ele renovou a cena pernambucana de acordo com os preceitos modernos ${ }^{7}$ que já haviam alterado os rumos do teatro no Rio de Janeiro e em São Paulo. Essa sucessão (do Gente Nossa para o TAP), segundo ele, é marcada pela continuidade entre os dois grupos: "[...] houve uma ligação no tempo; a um movimento seguiu-se o outro, tornando-se a atitude mais natural dos estudiosos a pesquisa da continuidade histórica dos fatos" (PONTES, 1966, p. 44).

No entanto, para Joel Pontes, só com o TEP, a partir de 1946, é que o teatro pernambucano superou a "desatualização" de sua dramaturgia ao valorizar e adotar "certas ideias surgidas no próprio Recife, em âmbito bem mais amplo que o somente estético - as do Movimento Regionalista de 1926, levantadas por um amigo de Samuel Campelo, Gilberto Freyre..." (PONTES, 1966, p. 35). Com o TEP, houve a retomada de uma linha regionalista ainda pouco desenvolvida na dramaturgia (PONTES, 1966, p. 81).

A exemplo desse grupo, Joel Pontes defende que era preciso que o povo se reconhecesse naquilo que fosse levado aos palcos. "Toda uma literatura

\footnotetext{
7 No âmbito dos estudos sobre a história do teatro brasileiro, a década de 1940 é considerada, normalmente, e, sobretudo por importantes estudiosos, como Sábato Magaldi e Décio de Almeida Prado, como o período em que se inicia a sua modernização. Com algumas discordâncias, esse argumento tem sido o mais aceito até o presente momento, destacandose que naqueles anos ocorreu o decisivo encontro entre grupos teatrais brasileiros e encenadores europeus, como Zbigniew Ziembinski e Zygmunt Turkow, que teriam trazido para cá as inovações cênicas que acabaram configurando a nossa modernidade teatral. Modernizar o teatro significava, neste contexto, tornar o encenador (diretor) "mais importante" que o autor de uma peça e que a "estrela da companhia", ou seja, aquele ator cujo prestígio lhe garantia um lugar acima do texto, dos demais componentes do elenco e de todos os elementos cênicos. Esta mudança resultou numa maior unidade do espetáculo, na medida em que o encenador poderia conduzir o conjunto de todos os elementos que compõem uma peça de forma mais harmônica. Além disso, a modernidade teatral implicou, ainda, na valorização da cenografia, iluminação e figurinistas dentro de uma montagem. E quanto aos temas, os mais reflexivos e críticos, que não levavam a um mero divertimento, como antes era comum no teatro brasileiro, passaram a receber maior atenção.

8 O Teatro de Amadores de Pernambuco foi criado como departamento autônomo do Gente Nossa. Valdemar de Oliveira, criador do departamento, e na época, diretor-geral do Gente Nossa foi o responsável pelo encerramento das atividades do elenco profissional e pela decisão de dar prioridade para o fortalecimento do TAP.
} 
teatral pode ser erguida com base nos tipos, problemas, acontecimentos, contos e costumes da região. Se o Gente Nossa, O TEP e os demais lançaram seus próprios dramaturgos, por que não seguir esse caminho certo e necessário?" (PONTES, 1966, p. 96).

Joel Pontes aponta, então, para a criação de dois paradigmas dentro do teatro pernambucano e fixa um antagonismo que frequentemente passará a ser considerado: a rivalidade que coloca em lados opostos o TAP, com um teatro aburguesado, voltado para a satisfação das elites; e o TEP, se colocando como porta-voz das camadas populares da sociedade pernambucana para difundir a sua cultura. Para o autor, "a atitude comparativa se explicava por serem o TEP e - TAP as expressões máximas no setor, e pelo antagonismo de suas condutas" (PONTES, 1966, p. 77).

Depois do Gente Nossa, do TAP e do TEP, o TPN é o quarto grupo que mais recebe atenção na obra, embora, bem menor que a dedicada àqueles três. Na verdade, cindida pelo limite do recorte temporal proposto (1931-1961), a trajetória do grupo é pouco discutida, mas suficientemente para que fosse evidenciado o seu compromisso com os mesmos princípios que nortearam o TEP e, consequentemente, também com o regionalismo nordestino.

Nesta perspectiva, Joel Pontes estabelece uma leitura particular para a história do teatro pernambucano. Uma leitura delimitada por uma tese e um recorte temporal. Assim, da década de sessenta, mereceriam ser considerados apenas os anos de 1960 e 1961. O autor até avança para os dois anos seguintes, mas apenas para fazer considerações pontuais. Caso tivesse estendido seu recorte para incorporar também esses dois anos (1962 e 1963), poderia ter falado mais sobre o TPN e sobre as experiências do Teatro de Cultura Popular, por exemplo, que apesar de sua proposta inovadora no contexto do teatro pernambucano, mereceu, ao lado de quase todos os outros grupos citados para além do Gente Nossa, TAP, TEP e TPN, poucas e insuficientes considerações para que fossem considerados em sua alteridade. Eles ficam sempre à mercê de comparações mais ou menos evidentes em relação às conquistas e características desses quatro grupos mais destacados. 
O trabalho de Joel Pontes contribuiu para a criação de balizas importantes para a compreensão da história do teatro pernambucano, como já será possível perceber no próximo tópico, na análise de uma obra bem mais recente, $O$ teatro em Pernambuco, lançada em 2005.

\section{teatro em Pernambuco}

O autor de O teatro em Pernambuco é Alexandre Figueirôa. Mestre em Artes pela Escola de Comunicação e Artes da Universidade de São Paulo e doutor em Estudos Cinematográficos e Audiovisuais pela Universidade Paris 3 Sorbonne Nouvelle, Figueirôa acumula ainda em seu currículo experiências como jornalista, crítico de cinema, pesquisador e professor adjunto do Departamento de Comunicação Social da Universidade Católica de Pernambuco. E embora seja conhecido pelos seus trabalhos sobre cinema, na primeira década deste século se destacou também com suas pesquisas acerca do teatro pernambucano, tendo publicado além de O teatro em Pernambuco, o livro Transgressão em 3 atos, de 2011, este como organizador.

O Teatro em Pernambuco foi lançado em 2005, uma época de mobilizações em defesa da retomada do chamado teatro de grupo . Essa movimentação havia se iniciado no final dos anos noventa com pelo menos duas importantes iniciativas: o I Festival Recife de Teatro Nacional, organizado pela prefeitura do Recife e o projeto Memórias da Cena Pernambucana.

No entanto, apesar dessa experiência vivenciada pela comunidade teatral local, O Teatro em Pernambuco não foi uma resposta a uma demanda específica do meio teatral. A publicação foi resultado de uma política editorial da Assembleia Legislativa pernambucana que teve como objetivo principal difundir a cultura do estado, o que é posto em prática de acordo com os princípios regionalistas há muito consagrados em Pernambuco e que fazem pensá-lo como o centro da região Nordeste. O deputado Romário Dias, autor do texto "Expressões da terra e da gente", que apresenta a obra, assim se manifesta: "As

\footnotetext{
9 Diferente das experiências de produtoras de elencos que montam peças pontuais, visando sobretudo uma aceitação fácil do público, o teatro de grupo é feito por conjuntos teatrais reunidos em torno de pesquisa continuada e um repertório próprio.
} 
nossas manifestações culturais, nas letras e nas artes, formam um vasto painel do ambiente, da paisagem e da vida de toda uma região. Elas consagram formas de expressão, de comunicação, em parte comuns ao Nordeste, ao País, e marcantes na vida da Nação" (FIGUEIRÔA, 2005, p. 5).

Já no prefácio, Antonio Cadengue afirma que um livro como O teatro em Pernambuco, que busca "minimamente" compreender a história do teatro no estado apesar da "seleção, omissão, concisão, além dos fatores subjetivos" que se impõem a todo estudo, significa "ultrapassar a morte, o esquecimento, trazendo à cena os actantes de uma história inscrita na memória coletiva, quase obscurecida" (FIGUEIRÔA, 2005, p. 8). Em seguida, cita outros autores que também se lançaram ao desafio de tentar "deter o tempo" e que foram "plasmados" por Figueirôa: Pereira da Costa, Samuel Campello, Valdemar de Oliveira, Milton Baccarelli, Luiz Maurício Carvalheira e, "sobretudo, Joel Pontes" (FIGUEIRÔA, 2005, p. 8). Neste caso, é muito pertinente destacar a forma como Cadengue conecta Joel Pontes à Figueirôa. O "sobretudo" é indicativo da influência das teses do autor de O teatro moderno em Pernambuco para a obra em questão.

Por sua vez, na introdução da obra, o próprio Figueirôa faz uma lista destacando "alguns bons trabalhos" que podem ser considerados referências para o estudo do teatro pernambucano. Note-se que o autor acrescenta Antonio Cadengue, o autor do prefácio de seu livro; Joel Pontes e Luiz Maurício Carvalheira (FIGUEIRÔA, 2005, p. 11).

Quando Edward Said diz que o Orientalismo é um sistema para citar obras e autores, fala de uma formação discursiva cuja unidade de um grande conjunto de textos que a constitui se baseia no fato de que eles estão continuamente se referindo um ao outro.

O Orientalismo é afinal um sistema para citar obras e autores. Manners and customs of the modern Egyptians, de Edward William Lane, era lido e citado por figuras tão diversas como Nerval, Flaubert e Richard Burton. Era uma autoridade de uso imperativo para quem escrevesse ou pensasse sobre o Oriente, e não apenas sobre o Egito [...]. (SAID, 2007, p. 54, grifo do autor) 
Com a criação de uma historiografia sobre o teatro pernambucano aconteceu algo semelhante. Enquanto formação discursiva, ela foi se constituindo dentro de um círculo muito restrito com sua própria coerência, no qual poucos autores se destacaram. E tal como o Orientalismo, teorizado por Said (2007, p. 53), esta historiografia também possui seus "pioneiros" (como Joel Pontes), "autoridades patriarcais" (como Valdemar de Oliveira e Hermilo Borba Filho), "textos canônicos" (como O teatro moderno em Pernambuco), "figuras exemplares"; "seguidores"; "elaboradores" e "novas autoridades".

Das quatro obras selecionadas nesta pesquisa, certamente é a de Figueirôa aquela que mais necessita se basear na autoridade de autores consagrados, uma vez que ela pouco dispõe de fontes obtidas diretamente de arquivos.

Também é revelador o que o autor considera serem "lacunas importantes", apesar dos estudos que já foram realizados. Segundo Figueirôa, o Grupo Gente Nossa, o Teatro Popular do Nordeste, o Teatro do Adolescente do Recife, a Companhia Brasileira de Comédia de Barreto Júnior e o Teatro Universitário de Pernambuco "ainda não foram alvo de um estudo mais profundo por parte de nossos pesquisadores" (FIGUEIRÔA, 2005, p. 11).

Esses grupos, no entanto, se constituíram entre os anos trinta e o ano de 1960, ou seja, Figueirôa, apesar do tema de sua obra ser "o teatro em Pernambuco", não se sentiu motivado a destacar uma lacuna a ser preenchida nos anos sessenta, o que poderia levá-lo a pensar em grupos que atuaram neste período. Em 2005, o autor tinha plenas condições de prolongar seu recorte até quando achasse relevante o teatro feito em Pernambuco, mas acabou adotando praticamente o mesmo marco final do recorte de Joel Pontes, escolhido quarenta anos antes. Ele faz um levantamento até 1963, chegando a citar fatos de 1968 em um pouco generoso posfácio. Sobre a sua forma de compreender o tempo do teatro em Pernambuco, Figueirôa afirma que

O teatro pernambucano, acredito, viveu seu momento mais intenso entre as décadas de 40 e 60. Foi nessa fase que deixamos de ser espectadores para tornamo-nos também protagonistas do movimento teatral brasileiro e referência na arte de escrever e encenar para o palco. E foi nesse período que os estudiosos das artes cênicas cunharam a expressão "Escola do Recife" para 
identificar essa efervescência criativa. Diante dessa constatação, acompanhar o teatro em Pernambuco desde seus primórdios, de modo a poder estabelecer a linha evolutiva que atingiu o ápice com as experiências do teatro popular, pareceu-me a opção mais coerente. Ao estabelecer como ponto final desta obra o momento imediato após a mudança brusca do regime político brasileiro, em 1964, levei em consideração a profunda transformação sofrida, a partir de então, pela cultura brasileira - vítima da repressão policial e da censura - e que, de certa forma, interrompeu, ou, ao menos, modificou os rumos de nossos artistas. (FIGUEIRÔA, 2005, p. 11, grifo do autor)

Alexandre Figueirôa acomoda-se dentro de uma formação discursiva que já teria encontrado a medida final para as narrativas acerca do teatro pernambucano. E em nome dela, ele nomeia, classifica e exclui protagonistas daquela cena. Inclusive, admite, como fez Joel Pontes, que ocorreram omissões inevitáveis, "algumas por opção, outras pelo fato de alguns episódios ou personagens não estarem registrados nas fontes utilizadas, constituídas basicamente de obras bibliográficas e trabalhos acadêmicos" (FIGUEIRÔA, 2005, p. 11).

Em O teatro em Pernambuco, ele escolhe permanecer na mesma linha evolutiva consagrada, quarenta anos antes, por Joel Pontes e seguida por outros pesquisadores que vieram depois. Figueirôa pode até ter um recorte temporal maior ou dar mais detalhes a aspectos e grupos que os seus antecessores não destacaram tanto, mas a narrativa é fundamentalmente a mesma e estabelece uma trajetória exemplar que vai do Gente Nossa ao TPN em sua primeira fase.

Toma-se uma história específica do teatro pernambucano, com suas conexões possíveis, como se fosse toda a história desse teatro (o "teatro em Pernambuco" que é o título do livro de Figueirôa), como se fora desse roteiro, as experiências do teatro de Pernambuco não permitissem uma inteligibilidade. Esse é princípio da historiografia moderna: separar o presente do passado, e em separando um do outro, no passado se "faz uma triagem entre o que pode ser 'compreendido' e o que deve ser esquecido para obter a representação de uma inteligibilidade presente" (CERTEAU, 2011, p. XVII). O teatro de Pernambuco ganha, assim, uma origem e uma evolução linear característica, e ignora-se que o passado do teatro local é no limite uma ambiência marcada por um caos acontecimental, que historicamente vai sendo ordenado. 
Efetivamente, o que é um acontecimento senão aquilo que é preciso supor para que a organização dos documentos seja possível? Ele é o meio pelo qual se passa da desordem à ordem. Ele não explica, permite uma inteligibilidade. É o postulado e o ponto de partida - mas também o ponto cego - da compreensão. "Deve ter acontecido alguma coisa", aí, diante das constatações que possibilitam construir séries de fatos ou transitar de uma regularidade para outra. Bem longe de ser o alicerce ou a marca substancial na qual se apoiaria uma informação, ele é o suporte hipotético de uma ordenação sobre o eixo do tempo, a condição de uma classificação. Algumas vezes ele não é mais do que uma simples localização da desordem: então, chama-se acontecimento o que não se compreende. Através desse procedimento, que permite ordenar o desconhecido num compartimento vazio, disposto antecipadamente para isso e denominado "acontecimento", torna-se pensável uma "razão" da história. Uma semantização plena e saturante é, então, possível [...]. (CERTEAU, 2011, p. 104, grifo do autor)

Nesse processo de desacontecimentalização do passado, o grande fluxo discursivo dos vencedores equivale ao silenciamento dos vencidos, daquilo que foi recalcado, ou seja, daquilo que uma compreensão do passado que se consolidou "considera como não pertinente - dejeto criado pela seleção dos materiais, permanece negligenciado por uma explicação [...]” (CERTEAU, 2011, p. $X V I I)$.

Como em Joel Pontes, o passado da cena pernambucana é remontado retrospectivamente de modo que dois modelos bem caracterizados e, de certa forma, estereotipados, o do TAP e o do TEP, pudessem surgir como a medida final para aquele teatro. Surge, assim, uma narrativa definida linearmente e baseada numa operação historiográfica que classifica o que deve ser compreendido e o que deve ser esquecido.

A última parte do livro, intitulada "Novos tempos", trata da fase em que se deu o ápice do teatro pernambucano o que, segundo Figueirôa, acontece quando se consagram as experiências de um teatro popular. Aqui, mesmo que não seja de forma tão entusiasmada como fez Joel Pontes, o que ganha destaque é o regionalismo, que teria transformado o teatro pernambucano em um efetivo protagonista da cena nacional. Segundo Figueirôa, isso teria começado de fato 
[...] em janeiro de 1957, durante o I Festival Nacional de Teatro Amador, quando o conjunto [dirigido por Clênio Wanderley], o Teatro do Adolescente, conquistou o primeiro prêmio com a peça de Ariano Suassuna, Auto da Compadecida.

De fato, essa encenação do Auto da Compadecida pode ser considerada um marco no teatro pernambucano pelo que essa montagem significou no sentido de corporificar uma série de ideias, propostas, intenções e modelos que estavam em gestação na cultura local e cujo nascedouro havia sido o TEP e o ápice, ocorreria dali a pouco tempo, com o Teatro Popular do Nordeste (TPN). Desde o final dos anos 40, já se usava a expressão "O Teatro do Nordeste", empregada pela primeira vez por Paschoal Carlos Magno quando veio ao Recife em 1948. Carvalheira observa que, desde 1950, esse teatro era algo que "se fazia sentir de maneira sensível, insofismável" com o Auto de João da Cruz, de Ariano Suassuna. Segundo ele, o auto iniciava um gênero novo: a comédia sacramental nordestina. "Enquanto Hermilo tentava uma recriação dos mitos gregos, as peças de Suassuna desaguavam na corrente ibérica continuamente recriada pelo cancioneiro nordestino". E foi Hermilo quem apontou, no auto, o caminho a ser seguido pelo Teatro do Nordeste. (FIGUEIRÔA, 2005, p. 79-80, grifo do autor)

Com esse enunciado, Figueirôa estabelece uma genealogia para o chamado Teatro do Nordeste ${ }^{10}$ que teria colocado o "teatro pernambucano nos palcos dos acontecimentos nacionais". O autor destaca que, ao alcançar a sua maturidade no final da década de 1950, esse teatro ofereceu um dos marcos da moderna dramaturgia brasileira que então surgia: O Auto da Compadecida. Essa peça e seu autor, Ariano Suassuna, ganham, portanto, credenciais para serem posicionados entre outros importantes marcos da dramaturgia nacional: $A$ Moratória, de Jorge de Andrade (1955); Eles não Usam Black-Tie, de Gianfrancesco Guarnieri (1958); Chapetuba Futebol Clube, de Oduvaldo Viana Filho (1959); e O Pagador de Promessas, de Dias Gomes e Revolução na América do Sul, de Augusto Boal, ambas de 1960 (FIGUEIRÔA, 2005, p. 89).

A história do teatro de Pernambuco encontra, assim, um lugar na historiografia do "teatro nacional". Mas esse lugar não pode ser naturalizado uma vez que essa historiografia não leva em conta uma equitativa justaposição de todo o teatro que se fez no país. Ao contrário, relativamente à Pernambuco, ela

\footnotetext{
10 "Teatro do Nordeste", um teatro que teria a finalidade de representar a realidade e o homem nordestinos por meio de uma linguagem nordestina caracterizada por sotaques e vícios de linguagem estereotipados, apesar de na prática e, basicamente, ele expressar as vivências dos homens e mulheres do sertão e zona da mata pernambucanos.
} 
deve ser percebida como espaço de um outro, já que tem como base fundamental a história do teatro que se fez e faz no Rio de Janeiro e em São Paulo, basicamente. E por essa razão, para Pernambuco entrar nessa ambiência deveria atender a certos critérios.

Nesse caso, cabe citar o importante trabalho de Rosângela Patriota e J. Guinsburg, Teatro brasileiro: ideias de uma história. Nessa obra, os dois estudiosos do teatro mostram como surgiu essa historiografia do teatro nacional e quais foram as ideias-forças que orientaram suas diferentes narrativas ao longo do tempo, do século XIX aos anos noventa do século passado. Essas ideias foram, pela ordem, a questão nacional, a modernização-modernidade e o nacionalismo crítico.

Uma vez estabelecida uma ideia-organizadora para o discurso historiográfico de um determinado período, os acontecimentos artísticos são normalmente apresentados e interpretados retrospectivamente de modo que um fio condutor possa dar coerência interna aos acontecimentos para que um ideário almejado pudesse ser confirmado. Nessa operação, normalmente a diversidade é suprimida a fim de que esse fio condutor possa ser colocado em prática, "muitas vezes, como força contrária à dinâmica teatral constituída historicamente" (GUINSBURG; PATRIOTA, 2012, p. 108).

A historiografia do teatro pernambucano assumiu, sobretudo, a ideia da modernização e a questão do nacionalismo, no caso, mediada por uma questão identitária notadamente regionalista. Essas duas ideias praticamente se fundiram na historiografia pernambucana. E influenciado por elas, os seus estudiosos utilizaram os marcos e a cronologia do "teatro nacional" a fim de darem um sentido para a trajetória do teatro local. "Se Os Comediantes modernizaram o teatro nacional, quem fez isso em Pernambuco?"; essa se torna uma questão importante dentro dessa lógica.

Assim, enquanto a historiografia que pretensamente pensa o teatro nacionalmente só reconhece em Pernambuco aquilo que reflete o fio condutor que utiliza para confirmar suas certezas, as narrativas produzidas localmente sobre o teatro pernambucano, se esforçam pelo reconhecimento de seu valor, levando em conta os mesmos parâmetros usados para analisar o teatro dos 
grandes centros do país. Daí a preferência por grupos que, localmente, não apenas podem representar de forma adequada o seu estado, refletindo a pernambucanidade, mas também que foram criados a partir de horizontes de expectativas semelhantes aos de seus congêneres da região sudeste.

Figueirôa legitima essa tendência, como podemos perceber na citação abaixo. O TAP, TEP e TPN são citados entre os grupos do eixo Rio-São Paulo.

Junto com esses autores [Jorge de Andrade, Ariano Suassuna, Gianfrancesco Guarnieri, Oduvaldo Viana Filho, Dias Gomes e Augusto Boal], surgiriam experiências que mudariam a face da dramaturgia nacional, como a do Teatro de Arena. Criado em São Paulo, 1953, por José Renato, o seu objetivo era abrir caminhos aos iniciantes, propondo-lhes uma disposição cênica com os atores no centro e os espectadores ao redor, o que facilitava a formação de novas companhias pelo barateamento da produção. Com a participação de Boal, Guarnieri e Oduvaldo Viana Filho, o conjunto incorporou influências que o projetaram nacionalmente e marcaram o teatro brasileiro na década seguinte. A originalidade do Arena foi sobretudo não ignorar o estético, mas procurar não o dissociar do panorama social em que o teatro deve se integrar. Assim, enquanto a geração de Os Comediantes e do TBC contentaram-se em fazer bom teatro, os novos grupos passaram a formular questões do papel do teatro enquanto instituição social e o que ele teria a dizer aos artistas e à sociedade. Décio de Almeida Prado observa que, no Recife, esses acontecimentos foram reiterados, quando não antecipados, obedecendo à mesma lógica. O TAP, apesar de amador, representava o papel do TBC. Usava repertório estrangeiro, contratava encenadores de fora, buscava equilíbrio entre o sucesso comercial - mesmo que o dinheiro fosse para ser doado - e o sucesso artístico. Em oposição, havia os grupos amadores desfraldando desde cedo a bandeira do nacionalismo e da popularização do espetáculo, cujo melhor exemplo havia sido o TEP, com Hermilo Borba Filho como condutor de uma outra maneira de vivenciar a cena. E foi novamente Hermilo, ao lado de Ariano Suassuna e de outros pernambucanos, que protagonizariam a experiência do Teatro Popular do Nordeste. (FIGUEIRÔA, 2005, p. 89-90)

Figueirôa, portanto, concorda que os acontecimentos no Recife obedeciam à mesma lógica daquilo que acontecia no eixo Rio-São Paulo, e retoma os mesmos marcos já observados em Joel Pontes: O TAP era o grupo sofisticado que tinha preferência por textos estrangeiros e, em oposição a ele, surgem grupos preocupados com questões identitárias: o TEP e o TPN.

Teatro moderno em Pernambuco e Teatro em Pernambuco, desta forma, separados por um período de quase quarenta anos, comprovam o vigor de uma 
narrativa particular a respeito do teatro em Pernambuco. Nessa narrativa, que elege o período que vai dos anos 1940 ao início dos anos sessenta como um período áureo, a década de sessenta fica praticamente ausente, só merecendo destaque seus anos iniciais. De 1965 em diante, praticamente nada é revelado.

Por um teatro do povo e da terra: Hermilo Borba Filho e o Teatro do Estudante de Pernambuco

A próxima obra analisada foi escrita por Luiz Maurício Carvalheira e publicada pela primeira vez em 1986, portanto, vinte anos após o lançamento do livro de Joel Pontes. E entre uma obra e outra, o teatro em Pernambuco mudou drasticamente. Para Figueirôa, como vimos, ele perdeu o rumo a partir do golpe de 1964 e por isso, a partir daí, não trouxe nada de relevante para ser relatado em seu livro. No entanto, ao invés de um "teatro vazio", existiu um teatro feito por jovens com projetos cênicos e ideológicos múltiplos, resistente aos condicionamentos impostos pela chamada "sociedade civil" e ao autoritarismo dos militares no poder, e, sobretudo, um teatro que procurava ir além dos paradigmas legados pelo TAP e TEP (CAVALCANTE JÚNIOR, 2017). Um teatro, portanto, fragmentado, mas não “vazio”.

Todavia, Carvalheira também não se interessou pelo teatro em Pernambuco desse período pouco prestigiado. Ao contrário, além de recorrer com frequência ao livro de Joel Pontes, como ele mesmo admite em sua introdução, ele escolheu trabalhar justamente com um teatrólogo e um grupo já consagrados: Hermilo Borba Filho e o Teatro do Estudante de Pernambuco. Nesse caso, sua história de vida revela algo importante para a sua opção.

Ele ingressou no Teatro Popular do Nordeste na sua segunda fase, em 1966, aos vinte e um anos. Conheceu Hermilo e logo o líder do grupo tornou-se o principal responsável pela sua formação teatral. Segundo o próprio Carvalheira revela, muito do que aprendeu em teatro devia a Hermilo "e ao grupo que dirigiu, quando então perseguíamos, com a teimosia caraterística dos nordestinos, o sonho de um grupo profissional que dignificasse a arte cênica em nossa terra. Desde essa época, em que trabalhamos juntos, não mais o perdemos de vista" (CARVALHEIRA, 2011, p. 53). Por isso, há um afeto a considerar por trás de sua 
narrativa, na medida em que o texto se propõe a falar justamente da trajetória, ideias e realizações de Hermilo Borba Filho no teatro em Pernambuco, enfatizando suas experiências no TEP e com algumas poucas considerações sobre o TPN. Assim, foi publicado Por um teatro do povo e da terra, que foi fruto de sua pesquisa de pós-graduação no programa de Mestrado em Teatro, na Escola de Comunicação e Artes, da Universidade de São Paulo, no início da década de 1980.

A obra não tem nenhuma pretensão de falar sobre o teatro pernambucano de forma mais ampla, como foi o caso de Joel Pontes e de Alexandre Figueirôa, logo não seria útil procurar encontrar em sua narrativa uma correspondência tão imediata com as questões levantadas na macronarrativa que vem sendo aceita nos últimos cinquenta anos. Ou seja, Carvalheira não adota uma linha narrativa que vai do Gente Nossa ao TPN nos primeiros anos da década de sessenta ${ }^{11}$.

No entanto, colabora com aquela narrativa consagrada na medida em que se tornou uma importante referência para se conhecer o teatro pernambucano pelo que há de consagrado: Hermilo Borba Filho, o TEP e, mesmo que em menor proporção, o TPN em sua primeira fase. No caso deste último, embora Carvalheira faça também algumas poucas referências às suas segunda e terceira fases ${ }^{12}$, o faz tão somente para enfatizar o legado de Hermilo e do TEP. Ou seja, a rigor não fala do TPN, mas do TEP e do Hermilo dos anos quarenta encarnados nos anos sessenta e setenta.

Optamos, finalmente, por apresentar no primeiro capítulo um quadro geral dessa trajetória, indicando as características fundamentais do que vem a ser a proposta teatral de Hermilo Borba Filho para, em seguida, focalizando o TEP, tentarmos empreender o caminho de volta buscando esse teatro em sua gênese, revelando e procurando interpretar as fontes e os pressupostos de uma arte cênica brasileira e nordestina. (CARVALHEIRA, 2011, p. 40)

\footnotetext{
${ }^{11}$ Chama-nos atenção, no entanto, que o prefaciador da segunda edição da obra, Maximiano Campos, faz questão de comentar: "Não estou, também, esquecido de que é digna de reflexão e estudo a contribuição dada pelo grupo Gente Nossa, liderado por Samuel Campelo, e o Teatro de Amadores de Pernambuco - ainda atuando - e que deve a sua criação a valdemar de Oliveira" (CARVALHEIRA, 2011, p. 30).

12 Para Carvalheira, o TPN teve três fases. A primeira vai de 1960 a 1963; a segunda, de 1965 a 1970 e a terceira, seria um breve retorno do grupo em 1974 (CARVALHEIRA, 2011, p. 61).
} 
O que Por um teatro do povo e da terra faz é verticalizar questões relativas a Hermilo e ao TEP, o que obviamente Joel Pontes não fez por não ter se proposto a falar tão detalhadamente do grupo. Mas o encaminhamento dado pela obra O teatro moderno em Pernambuco, naquilo que diz respeito ao TEP e seus investimentos regionalistas, está contemplado na narrativa de Carvalheira. Nenhum dado novo é apresentado sobre o teatro em Pernambuco dos anos sessenta, exceto aquilo que foi aperfeiçoado da busca que Hermilo e o TEP iniciaram nos anos de 1940. As ideias que deram vida ao TPN nos anos sessenta são tratadas dessa forma.

Da sua segunda fase chega a afirmar que o TPN trouxe "mais nitidamente em sua fisionomia a marca de grupo experimental" (CARVALHEIRA, 2011, p. 71), se referindo à sua busca por uma arte cênica nordestina pautada nos próprios espetáculos populares como o bumba-meu-boi, por exemplo. Mas não avança em mais detalhes. E com relação ao breve retorno que constituiria sua terceira fase, Carvalheira chega a afirmar que, na época, Hermilo apresentava "novas preocupações, sobretudo com relação a um teatro de temática urbana, que tratasse de questões como a do êxodo rural e da vida do homem nos grandes centros" (CARVALHEIRA, 2011, p. 75) e nada mais. Não explica a influência das mudanças sociais, políticas e culturais do final dos anos sessenta e começo dos setenta sobre a mudança nos interesses de Hermilo. Ao contrário, ignorando esse contexto, o que o autor faz é buscar no passado a origem para essas novas ideias: "essa maneira de pensar e agir origina-se no tempo do Teatro do Estudante de Pernambuco, quando o pensamento de Hermilo, aliado à prática, finca as primeiras raízes nos terrenos percorridos com os estudantes" (CARVALHEIRA, 2011, p. 75).

Assim, o que Carvalheira fez foi apresentar, inicialmente, um quadro geral relativo à proposta teatral de Hermilo Borba Filho, que orientou o TPN nos anos sessenta e setenta para, em seguida, no momento seguinte de sua narrativa, resumi-la a uma fórmula familiar aos anos quarenta a fim de mostrar retrospectivamente como o Teatro do Estudante de Pernambuco foi a origem de tudo: focalizando o TEP e tentando "empreender o caminho de volta buscando esse teatro em sua gênese, revelando e procurando interpretar as fontes e os pressupostos de uma arte cênica brasileira e nordestina" (CARVALHEIRA, 2011, p. 
40). Dessa forma, as diferenças que o TPN acabou apresentando em relação ao TEP, a partir da segunda metade dos anos sessenta, foram elididas para que uma ideia-força pudesse ser preservada, aquela que defende que o caminho do ser nacional passa pelo regional, como pensava Hermilo nos tempos do TEP. Não por acaso, a obra se chama "Por um teatro do povo e da terra".

Portanto, embora as reflexões de Carvalheira avancem para além de 1964, esse período perde sua alteridade. Torna-se apenas um prolongamento de uma espécie de tempo contínuo e maravilhoso que se iniciou nos anos quarenta e só assim encontra sentido para ser considerado na sua obra. De forma semelhante ao que acontece com Figueirôa, que vê a partir de 1964 um teatro interrompido ou sem rumo em Pernambuco, Carvalheira, no seu livro, chega a afirmar que são os anos setenta que resultaram num "esvaziamento cultural" (CARVALHEIRA, 2011, p. 53).

Ambos os pesquisadores trabalham com a perspectiva de que em algum momento entre os anos sessenta e setenta iniciou-se um período difícil para se pensar o teatro de Pernambuco. Diante deste devir indesejado, Figueirôa optou por recalcar a história do teatro em Pernambuco a partir de 1964; já Carvalheira, decidiu viajar para São Paulo em busca de melhores condições para avaliar criticamente o trabalho de Hermilo.

Nesse caso, é preciso reconhecer que, ao se deslocar para São Paulo em busca de "melhores condições para estudar Hermilo Borba Filho", um teatrólogo que atuou em Pernambuco, Carvalheira se viu diante de uma ordem discursiva para a qual pesquisas e montagens de peças desenvolvidas no eixo Rio-São Paulo são consideradas representativas de um teatro normalmente designado como nacional, enquanto aquilo que é realizado em outras regiões, como a Nordeste, é tratado como teatro regional.

Dessa forma, levando-se em conta que "toda pesquisa historiográfica se articula com um lugar de produção socioeconômico, político e cultural" (CERTEAU, 2011, p. 47), a narrativa do pesquisador Carvalheira certamente se submeteu a certas imposições da instituição em que foi produzida, na tentativa de se adequar às leis que nela determinam o que é permitido e o que é proibido. “Como o veículo saído de uma fábrica, o estudo histórico está muito mais ligado 
ao complexo de uma fabricação específica e coletiva do que ao estatuto de efeito de uma filosofia pessoal ou à ressurgência de uma realidade passada. É o produto de um lugar" (CERTEAU, 2011, p. 57).

O discurso de Carvalheira sobre Hermilo e o TEP, no momento de sua produção, portanto, ganharia relevância se fixasse as propostas de Hermilo como investimentos antropologizantes e localizados, ou seja, se apresentasse a principal liderança do TEP como um legítimo representante do regionalismo nordestino, tal como frequentemente era e é classificado pelos estudiosos de São Paulo.

Então, para satisfazer os seus pares, os verdadeiros destinatários de um pesquisador, conforme Certeau (2011, p. 56), a Carvalheira seria interessante ou imprescindível investir num eixo narrativo que priorizasse o TEP, oferecendo, quando muito, apenas notas introdutórias sobre o TPN, e abrindo mão de estabelecer algumas reflexões importantes que poderiam pôr em risco a imagem do teatro regionalista em Pernambuco. Por exemplo, embora Carvalheira chegue a reconhecer Hermilo, nos anos setenta, em plena revisão das concepções que tinha sobre o teatro popular nos tempos do TEP ${ }^{13}$, ele pouco explora essa circunstância, que certamente colocaria em dúvidas a continuidade entre o Hermilo do TEP e o Hermilo dos anos setenta ${ }^{14}$. Negligenciando a revisão de Hermilo, Carvalheira aposta na continuidade, em um fio condutor que vai do TEP ao TPN sem sobressaltos.

\footnotetext{
${ }^{13}$ Quando ele passou a questionar: "Que é teatro popular? Por definição: aquele que é feito pelo povo. Existe um teatro popular? Claro: aquele que é representado pelos bumbas, pastoris, mamulengos, espetáculos dramáticos populares espalhados por toda a região nordestina". (BORBA FILHO, 1976 apud CARVALHEIRA, 2011, p.92)

${ }^{14}$ Podemos perceber que o pensamento teatral de Hermilo mudou consideravelmente a partir de cinco dimensões fundamentais: encenação, concepção acerca do popular, posições políticas, relação com o tempo e temática. Cenicamente, Hermilo adotou uma postura antiilusionista baseada nos espetáculos populares tal como apresentados pelos seus próprios brincantes; sobre o "popular", passou a acreditar que eruditos e pesquisadores são incapazes de fazer "teatro popular"; politicamente, atravessando uma fase em que a política deslocavase do macro para o micro e vivendo uma realidade difícil, marcada por um governo ditatorial, ele se tornou uma subjetividade insubmissa, que fazia questão de, em pequenos golpes, deixar claro o seu desacordo com a realidade que o cercava; no que diz respeito ao tempo, Hermilo, que no início do TEP, conclamava um retorno aos temas cotidianos do passado nordestino, a partir dos anos setenta, começou a apresentar uma perspectiva nova sobre o tempo, demonstrando estar bem menos ligado ao passado e mais engajado nas demandas próprias do tempo presente e por fim, tematicamente, procurou rever também os temas com as quais trabalhava desde os anos quarenta, o que o leva a escrever textos socialmente mais críticos e cada vez menos convencionais e, não por acaso, será taxado como um "autor maldito", por explorar o sexo sem "meias palavras".
} 
O pesquisador procurou estabelecer um nome próprio para Hermilo Borba Filho, um designador rígido e ritualizado de sua classificação (BOURDIEU, 2006, p. 187). Recriou sua vida como uma série única sem contradições a abalar sua identidade, o que para Pierre Bourdieu é uma impossibilidade já que uma trajetória deve sempre ser percebida como "série de posições sucessivamente ocupadas por um mesmo agente (ou um mesmo grupo) num espaço que é ele próprio um devir, estando sujeito a incessantes transformações" (BOURDIEU, 2006, p. 189).

Um Hermilo diferente, que rompesse com a sua visão tradicional de cultura popular e desejasse dar mais destaque ao meio urbano, seria um objeto de estudo um pouco menos interessante ou menos esclarecedor a respeito do teatro pernambucano sobre o qual, São Paulo, como um grande centro produtor de conhecimento, projetava a imagem de um outro relativo a si. Seria um Hermilo marginal à ordem do discurso que se estabeleceu com a formação de uma historiografia do teatro brasileiro já há algum tempo consagrada, que nacionaliza centripetamente as diversas manifestações teatrais do Brasil.

Para analisar a construção da historiográfica sobre o teatro brasileiro, J. Guinsburg e Rosangela Patriota procuraram selecionar os trabalhos mais citados nas pesquisas realizadas sobre o assunto e, apesar de reconhecerem a existência de outros, constataram que os livros de J. Galante de Souza, Sábato Magaldi e Gustavo Dória são os mais presentes na bibliografia dos estudos sobre teatro brasileiro, seguidos, "em menor grau”, em algumas pesquisas, pelas reflexões de Lafayette Silva, Hermilo Borba Filho e Nélson de Araújo.

E segundo os autores, os textos de J. Galante, Sábato Magaldi e Gustavo Dória "militam efusivamente em favor da modernidade para os palcos brasileiros" (GUINSBURG; PATRIOTA, 2012, p. 89). Por sua vez, Lafayette Silva teria se ocupado de "eventos, manifestações, decisões governamentais, legislação, que trouxessem evidências em relação à atividade teatral no Brasil" (GUINSBURG; PATRIOTA, 2012, p. 90). Já em Hermilo Borba Filho e Nélson de Araújo, a ênfase no local na busca por uma identidade regional é aquilo que se deve destacar. 
[...] o acento local, como tentativa de inseri-lo no debate mais amplo, marcam a singularidade e a importância dessas investigações para o estudo do teatro em Pernambuco e na Bahia. Em outras palavras, as empreitadas propostas por Borba Filho e por Araújo, ao estabelecerem ênfase na busca das origens, isto é, nas raízes mais profundas que compõem e dão identidade às culturas produzidas em diferentes regiões do Norte e Nordeste do país, são contribuições imprescindíveis para que vislumbre a emergência de uma antropologização identitária como realização artística e como estratégia de investigação. (GUINSBURG; PATRIOTA, 2012, p. 89-90)

Nesta perspectiva, o discurso de Carvalheira, por um lado, se ajusta à expectativa da divulgação de uma cultura e identidade pernambucana fixas e estáveis por meio de um teatro tradicional (não por acaso, em 1986, a primeira edição de seu livro foi publicada pela Fundação do Patrimônio Histórico e Artístico de Pernambuco - Fundarpe) e, por outro, torna a historiografia do teatro de Pernambuco familiar à historiografia que trata do teatro numa dimensão "nacional".

Carvalheira demonstra o seu interesse em se alinhar a essa historiografia, sobretudo, ao defender para o teatro de Pernambuco o direito de ser reconhecido nos mesmos termos que o teatro dos grandes centros do país. Por essa razão, defende que se Os Comediantes merecem reconhecimento por terem sido os pioneiros da modernização do teatro nacional "é igualmente justo, em se tratando do Nordeste, que se atribua papel semelhante ao grupo de Valdemar de Oliveira" (CARVALHEIRA, 2011, p. 116).

Carvalheira também procura preservar o lugar social reservado ao TEP. Buscando a fronteira entre o popular e o erudito, esse conjunto chegou a ser acusado de montar peças que seriam inacessíveis ao povo ${ }^{15}$, mas mesmo tendo levantado essa questão, Carvalheira logo silencia-se sobre ela, o que contribui para a manutenção da imagem coerente de um grupo disposto a criar um teatro cada vez mais popular, em contraposição a um teatro voltado para as elites. E com isso, o velho dualismo TAP x TEP, também enfatizado por Carvalheira, como

\footnotetext{
15 No dia 22 de junho de 1950, a respeito da peça O vento do mundo, aparece o seguinte comentário no Jornal Pequeno: "O vento do mundo - diga-se de passagem - não é uma peça para o grande público, embora especialmente para ele tenha sido feita; é mais para as elites" (CARVALHEIRA, 2011, p. 265, grifo do autor)
} 
fizeram Joel Pontes e Figueirôa, é preservado enquanto elemento constituinte de uma narrativa consagrada.

Por fim, Carvalheira atesta o vigor do Teatro do Nordeste. O encaminhamento da discussão, assim como em Joel Pontes e em Alexandre Figueirôa, é no sentido de mostrar que a grande contribuição do teatro pernambucano ao teatro e à cultura nacional é de caráter identitário. Neste sentido, o autor, como os outros dois citados, destaca o avanço do teatro local em direção ao regionalismo (CARVALHEIRA, 2011, p. 60).

No entanto, a todo momento Carvalheira se coloca contra a ideia de um “teatro regionalista”, entendendo que ela expressaria algo meramente pitoresco e exótico. Para ele, o Teatro do Nordeste seria representativo da cultura brasileira e não de uma região apenas, embora não consiga explicar em bases históricas ou sociológicas de que modo ele poderia sensibilizar outras partes do país.

Mas chega a admitir na conclusão de seu trabalho que se o Teatro do Nordeste é caracterizado como algo "regionalista" e "exótico", a responsabilidade deve recair sobre os seus próprios artistas e intelectuais. Ele acredita que, em parte, isso se deve a uma "interpretação distorcida da cultura popular que the serve de suporte, em parte também é devido a uma fração da dramaturgia originária do Nordeste trazer em seu bojo, pelo mesmo motivo, as características apontadas" (CARVALHEIRA, 2011, p. 290).

Assim, o teatro com o qual Carvalheira se compromete ajuda a construir uma identidade regional a partir de Pernambuco, ou seja, um "Nordeste pernambucano". E certamente por isso, a leitura de Por um teatro do povo e da terra tenha se tornado ao longo das três últimas décadas, pelo menos nas palavras de Luís Augusto Reis, atualmente um dos principais pesquisadores do teatro pernambucano, "incontornável para quem pretende conhecer melhor o teatro e a cultura pernambucana” (REIS, 2011 apud CARVALHEIRA, 2011, p. 11).

TAP - sua cena e sua sombra: o Teatro de Amadores de Pernambuco (1941-1991)

A última obra de nossa seleção, TAP - sua cena e sua sombra: o Teatro de Amadores de Pernambuco (1941-1991), se constitui em dois grandes volumes, 
cada um com mais de quatrocentas páginas. Foi escrita inicialmente como dissertação de mestrado (1988) e tese de doutorado (1991) por Antonio Cadengue quando este passou pela pós-graduação na Escola de Comunicação e Artes, da Universidade de São Paulo.

Seu autor, professor aposentado da UFPE e diretor de teatro desde os anos 1970, como o próprio afirma no tópico "Sete notas prévias", estudou O TAP durante oito anos e o resultado alcançado foi um trabalho com grande vigor empírico, baseado em material de imprensa, que remonta os cinquenta anos de seu recorte temporal; na produção literária de Valdemar de Oliveira; nas peças do repertório do TAP; em programas, cartazes e outros documentos de espetáculos; fotos e entrevistas. E na falta de uma tese definida, é justamente a forte presença de documentação primária que garante os méritos e a importância deste trabalho para a historiografia do teatro pernambucano.

O objetivo da obra é tão somente "delinear um perfil das encenações do Teatro de Amadores de Pernambuco por meio das informações e críticas teatrais dispersas na imprensa, no período de 1941 a 1991" (CADENGUE, 2011a, p. 40). Esses cinquenta anos, no entanto, não se resumiriam à história do TAP. Primeiro porque Cadengue procura falar de outros grupos também. Segundo porque em sua perspectiva, o autor acredita que é do próprio teatro pernambucano que fala o tempo todo já que, para ele, é "impossível fazer a História do Teatro de Amadores de Pernambuco, sem estar fazendo, ao mesmo tempo, a História do Teatro em Pernambuco" (CADENGUE, 2011b, p. 385).

Sua narrativa, portanto, encontra espaço em nosso estudo, que busca perceber as práticas discursivas que contribuíram para a constituição de um regime de verdade a respeito da história do teatro pernambucano desde a obra de Joel Pontes, O teatro moderno em Pernambuco. Essa obra, por sinal, é citada com destaque também por Cadengue:

Apenas um trabalho mais sistemático estuda o TAP nos seus primeiros 20 anos: O Moderno Teatro em pernambuco (sic), de Joel Pontes. Em dois capítulos, enumera as inovações do TAP quando de seu surgimento e aponta o ecletismo como marca conservadora do grupo. Discretamente, sugere que, por não incluir em seu repertório peças de autores nacionais e regionais, o TAP 
influencia toda uma geração de diretores e grupos teatrais que, na escolha de peças para suas montagens, distanciam-se tanto do teatro nacional e pernambucano quanto da vanguarda internacional. Seu livro é extremamente bem cuidado e os fatos arrolados têm atinada interpretação, de forma sensível e inteligente. Ainda de grande atualidade. (CADENGUE, 2011a, p. 4041, grifo do autor)

A narrativa tradicional que procuramos delinear nesta pesquisa repercute na obra de Cadengue. Nela aparecem também desde o grupo Gente Nossa até o Teatro Popular do Nordeste do início dos anos sessenta. A diferença diz respeito aos detalhes, que Cadengue esmiúça com muito mais propriedade com sua vasta pesquisa documental, e ao alargamento do recorte temporal. Isso porque, diferente das outras obras aqui selecionadas, Cadengue rompe a fronteira do início da década de sessenta e faz considerações também ao teatro praticado nos anos sessenta e setenta. Mas isso ocorre apenas para estabelecer um contraponto à trajetória do TAP: “[...] são traçadas as fases da trajetória do conjunto, entrecortadas por diversos acontecimentos paralelos às atividades artísticas do TAP, mas a ele ligados, direta ou indiretamente, aqui denominados de Contraponto [...]" (CADENGUE, 2011a, p. 43, grifo do autor).

Desta forma, o teatro de Pernambuco encontra na narrativa de Cadengue um marco. O TAP torna-se a fonte de sua inteligibilidade. E é assim que a narrativa de Cadengue também alimenta a memória organizadora do teatro pernambucano como mais um texto a enfatizar a trajetória de um grupo teatral consagrado em Pernambuco.

Mas essa operação é tão sutil que Cadengue, mesmo contribuindo para a naturalização de uma formação discursiva, a ela se sente alheio. Ele acredita estar apenas descrevendo uma engrenagem, quando na verdade, TAP - sua cena e sua sombra tornou-se uma de suas peças fundamentais enquanto prática discursiva. Vejamos o que ele diz na conclusão de sua obra:

Hoje, a imagem do TAP é a da tradição, cujo estilo é a repetição. Ano a ano, a mesma cena é apresentada como novos arranjos retóricos. A cada aniversário do grupo, seus objetivos são veiculados pela imprensa da mesma maneira: rearticulam-se as frases sem alterar-lhes o sentido original. Disso, se orgulha. À medida que reproduz sua própria imagem, sem ensejar maiores mudanças e controlando os possíveis desvios, o grupo 
intemporaliza-se como um mito, querendo frear o tempo que corre implacável. Devolver-lhe sua temporalidade é devolvê-lo à História. Raison d'être deste trabalho.

De qualquer maneira, uma legenda eterniza-se: Valdemar de Oliveira. Seus feitos, sua paixão ardorosa pelo palco, seu devotamento irrestrito ao TAP, além da dignidade e da projeção dadas ao teatro do Recife, fazem com que seu nome já não pertença a Pernambuco, mas ao país. Em torno do TAP, gravita o teatro pernambucano desde sua fundação em 1941. Ele não é o único eixo, mas é inegável que se deduza o seu papel principal, senão até hoje, pelo menos até meados da década de 1960 (o que é muito relevante). (CADENGUE, 2011b, p. 382, grifo do autor)

Na citação, dois destaques a fazer. Primeiro: “À medida que reproduz sua própria imagem, sem ensejar maiores mudanças e controlando os possíveis desvios, o grupo intemporaliza-se como um mito [...]". Neste caso, é valioso considerar que Cadengue também aceitou o controle exercido pelo TAP, já que encaminhou a versão final do livro para que Reinaldo de Oliveira, o filho de Valdemar de Oliveira, que herdou a direção geral do TAP depois de sua morte, pudesse reexaminar informações, identificar fotos e autorizar a reprodução das mesmas (CADENGUE, 2011a, p. 29, grifo do autor) e que o próprio Reinaldo, em seu livro de memórias, considerou o livro de Cadengue, "perfeito" (OLIVEIRA, 2013, p. 17).

O segundo destaque é para o sentido que o autor dá à história do teatro Pernambucano. Depois que o TAP foi fundado, nada the seria alheio. Nem mesmo os grupos que se colocam explicitamente contrários a ele teriam uma trajetória singular. O TAP torna-se a origem a partir da qual o teatro pernambucano moderno, de uma forma ou de outra, se formou. Tal ideia inspirou Rudimar Constâncio a escrever, na apresentação da obra, que não escaparia a essa lógica nem um grupo como o Vivencial, que se notabilizou na década de 1970 pelo escracho de suas encenações e pelos seus membros pobres e marginalizados. Para Rudimar, o TAP ecoava nos grupos que surgem a partir dele ou em oposição a ele, "como o Teatro do Estudante de Pernambuco, o Teatro Adolescente do Recife, o Teatro Popular do Nordeste e o Grupo de teatro Vivencial” (CADENGUE, 2011a, p. 17).

É a partir do segundo capítulo que começa a narrativa da história do grupo, como prometido, a partir de descrições e explicações das suas montagens. Uma 
trajetória que, como o próprio Cadengue reconhece, é uma "inequívoca história de 'vencedores'" (CADENGUE, 2011b, p. 373). E para cumprir seus objetivos, no trato dos documentos que investiga, Cadengue, embora apresente questões novas ou pouco abordadas pela narrativa consagrada sobre o teatro de Pernambuco, acaba contribuindo para projetar uma história sem desvios em relação à memória oficial do grupo. Isso acontece porque ora ele adere explicitamente a alguns dos discursos consagrados que o próprio grupo produziu ou que produziram sobre ele com a sua concordância, ora porque ele os divulga sem uma análise.

Neste caso, entre as questões que ele apresenta com algum potencial para serem consideradas desviantes temos a sua composição do que seriam as cinco fases da longa trajetória do TAP: 1) As Primeiras Letras (1941-1947): é o momento em que o conjunto começa a fazer a diferença em Pernambuco, buscando se educar e educar seu público, objetivando a "dignificação da arte dramática" e promovendo a "filantropia". Torna-se um "teatro a ser imitado"; 2) A Renovação da Cena (1948-1958): é o momento em que o grupo de fato se moderniza, se atualizando com relação aos movimentos estéticos europeus que chegaram ao Brasil na década de 1940. É o momento mais ousado do grupo; 3) A Consolidação da Cena (1959-1965): momentos de refluxo do TAP, quando o esforço é para se consolidar as conquistas da fase anterior e com isso já não impressiona; 4) A Ordenação do Passado (1966-1976): com saudades de si mesmo, o grupo tornase alheio ao presente e se caracteriza por uma profunda nostalgia e 5) A Cena Refletida (1977-1991): fase marcada pela retomada da sua própria história. Existem tentativas de renovação e momentos de crises internas (CADENGUE, 2011a, p. 44-45).

Essa perspectiva apresentada por Cadengue poderia comprometer uma leitura plenamente inscrita na memória coletiva relativa ao teatro de Pernambuco. O TAP, afinal, nem sempre teria sido o mesmo. Isso atenta contra uma coerência atribuída à trajetória do grupo, segundo a qual os mesmos princípios do seu início norteariam até hoje a sua prática e que o grupo sempre teria sido uma vanguarda no teatro de Pernambuco. 
Tal "coerência", em grande medida, é resultado da "generosidade" com que o TAP era normalmente tratado pela crítica especializada. E essa proteção vinda de cronistas importantes, fato que colaborava com a preservação da imagem do grupo, também é uma questão levantada por Cadengue: “No Recife, um ou outro o desafia, mas, por sua hegemonia, muitas divergências permanecem à boca fechada. Quem ousa enfrentar esta esfinge amiga de praticamente todos os governos e instituições?" (CADENGUE, 2011a, p. 46).

Fora dessa ordem discursiva, dificilmente a ideia segundo a qual O TAP teve uma vitoriosa trajetória linear se manteria para além dos anos de 1950. Nesse caso, entre seus desvios mais notórios, se encontra aquele que diz respeito ao repertório do grupo. A constatação desse desvio poderia aproximar o TAP do TEP, a despeito de um regime de verdade que historicamente os situa como dois modelos diametralmente opostos.

Se, no início, o TAP ficou marcado por praticamente ignorar a dramaturgia nacional e regional, sobretudo depois do sucesso de sua montagem da peça regionalista Um sábado em 30, o grupo não apenas passa a valorizar a dramaturgia local, como chega a entrar na disputa pela memória do Teatro do Nordeste. Diz Valdemar de Oliveira, em sua coluna A Propósito, no dia 06 de outubro de 1965, que foi em decorrência do trabalho do TAP que "surgiram novos originais que levaram Pascoal Carlos Magno a apontar a existência de um Teatro do Nordeste, que nos deu Ariano Suassuna, José Carlos Cavalcanti Borges, Osman Lins, Aristóteles Soares, Luiz Marinho, outros".

Cadengue poderia ter explorado esse deslocamento, mas não o fez. Optou por transcrever, também sem analisar, a seguinte declaração de Ariano Suassuna, de 1966:

Agora eu pergunto: como é que um autor nordestino que tenha um mínimo de dignidade pode oferecer uma peça a um homem desses [Valdemar de Oliveira]? E o pior é que, depois disso, o diretor do TAP tem a coragem de dizer, de público, que o atual grupo de autores do Nordeste surgiu graças ao movimento iniciado por ele, quando a verdade é que nossas ideias e nossas peças se firmaram a despeito dele, em oposição a ele. (CADENGUE, 2011b, p. 90) 
Ou seja, apresentando empiria e sugerindo, deliberadamente ou não, novas questões problematizadoras sobre o grupo de Valdemar de Oliveira, sem uma tese ou um debate teórico, Cadengue em alguns momentos nos apresenta um dos grandes do teatro pernambucano como um estranho a si mesmo. Até críticas pouco comuns contra grupos tão festejados ganham espaço na narrativa de Cadengue por meio dos textos jornalísticos que cita. Sobre a montagem do TEP da peça Otelo, em 1951, ele apresenta o seguinte comentário do cronista Guerra de Holanda: "O espetáculo foi uma coisa pavorosa. Pavorosa e triste. O Teatro do Estudante não estava absolutamente em condições de representar Otelo. Nem condições culturais, nem condições financeiras" (CADENGUE, 2011a, p. 275).

Cadengue expõe fragilidades de um teatro pernambucano tradicional que dificilmente são tratadas pela historiografia. Tradicionalmente, grupos como o TAP e TEP são tratados a partir de representações com imagens impecáveis, de modo que uma crítica como essa, que põe em dúvida a qualidade técnica do TEP, é de fato incomum. Isso abre o flanco para uma revisão crítica da história do TAP, uma forma de contestar certas verdades que há mais de meio século se cristalizaram a respeito do grupo, o que Cadengue insinua em certos momentos, mas não o faz, assim como Carvalheira também não fez em certos momentos de seu texto sobre o TEP.

No caso de Cadengue, ele próprio admite assumir as dores do grupo que estuda como suas; ele "apropria-se da dor doída do grupo, fazendo destes fragmentos sua própria história" (CADENGUE, 2011a, p. 26). E assim, com esse grau de identificação, por mais que sugira de forma deliberada ou não questões dissonantes, estas não propulsionam uma nova leitura da história do TAP. Como as contradições apresentadas não são problematizadas devidamente, elas não chegam a ameaçar a identidade do grupo no seu sentido geral. Sua essência naturalizada fica preservada.

O que prevalece mesmo é a imagem de um passado em busca de consagração na medida em que é, nas palavras do próprio Cadengue, um "passado que traz consigo sinais misteriosos, que o impulsionam à redenção. Não apenas dele mesmo, mas de um teatro e de uma sociedade" (CADENGUE, 2011b, p. 373, grifo do autor). Nesse sentido, o autor também reverbera discursos 
tradicionais que ajudaram a constituir a fama do TAP. Agindo dessa forma, o autor também se torna um importante divulgador de tais ideias ou porque concorda explicitamente com elas ou por transcrevê-las sem nenhuma análise.

Por exemplo, a ideia de que a história do teatro pernambucano pode ser dividida em um antes e um depois do TAP é apresentada em pelo menos três momentos na obra (incluindo a apresentação) sem que nenhuma consideração que explicasse o que significa aderir a esta afirmação, do ponto de vista historiográfico, fosse feita. Atribuída ao crítico teatral Adeth Leite (CADENGUE, 2011b, p. 163), a afirmação ganha ares de verdade também na obra de Cadengue, instituindo um corte cirúrgico na história do teatro de Pernambuco e estabelecendo uma origem para a sua modernidade.

E de certa forma, ligada a essa primeira afirmação existe uma outra, que defende que sem o TAP, o que houve de melhor no teatro de Pernambuco não teria existido. Ela se multiplica em afirmações do tipo: "Se não fosse um idealista [Valdemar de Oliveira] teria ficado em meio do caminho e, hoje, do TAP não restaria vestígio; e em matéria de teatro pernambucano não teríamos nada”, do historiador pernambucano Nilo Pereira (PEREIRA, 1963 apud CADENGUE, 2011b, p.82) ou "Muito já se disse, mas não cansa repetir que não fora o TAP, muitos dos melhores originais da literatura teatral universal, jamais seriam conhecidos do público do Recife", do crítico Adeth Leite (LEITE, 1966 apud CADENGUE, 2011b, p. 167). Sem nenhum tratamento crítico, essas afirmações acabam atribuindo à história do teatro pernambucano um sentido único, uma evolução em linha reta que teria começado com o TAP e não poderia ter acontecido sob o protagonismo de ninguém mais. Uma história, pois, restritiva e contada retrospectivamente a partir de quem venceu, recalcando-se evidentemente a diferença.

Esse sentido já se manifestava nos discursos do próprio Valdemar de Oliveira. Sempre muito preocupado com as representações que se faziam a respeito de seu grupo e atento ao que era dito sobre ele, em 1949 declara em sua coluna A propósito: "Não fossem os 'Amadores', e jamais esse nosso público teria entrado em contato com o repertório que eles the têm mostrado, nem com as constantes inovações de suas montagens, nem com as mais recentes conquistas da arte de representar" (OLIVEIRA, 1949, p. 8, grifo do autor). 
Quanto ao recorte temporal utilizado nas quatro obras selecionadas, é possível ver uma ampliação na obra de Cadengue. Isso se reflete na quantidade de grupos que ele cita dos anos sessenta e setenta. No entanto, quando fala da realidade pós-golpe de 1964, ele repercute a ideia de que o teatro praticamente desapareceu em Pernambuco, como afirma Figueirôa. Isso fica explícito quando ele diz que "o teatro pernambucano passa a viver seus mais sombrios tempos[...]" (CADENGUE, 2011b, p. 117) e que "o teatro no Recife esvazia-se progressivamente", ficando o TAP “sozinho na reta” (CADENGUE, 2011b, p. 15).

A obra de Cadengue, portanto, por confundir a evolução do teatro de Pernambuco com a história do TAP que, segundo o autor, seria capaz inclusive de demarcar os limites e possibilidades para o fazer teatral até de grupos que procuraram se distanciar dele, também contribui de forma decisiva para inscrever ainda mais o teatro pernambucano numa memória organizadora.

\section{Considerações finais}

Este artigo se debruça sobre a verdade do teatro pernambucano como um ponto de chegada que queríamos alcançar e não como um ponto de partida, porque do ponto de vista teórico adotado, a verdade não existe por si mesma, ela é resultado de investimentos linguísticos que dizem o que é verdadeiro e o que é falso em um determinado momento e para uma determinada sociedade, a exemplo do debate teórico em que se envolveu Mendel em sua época. "Muitas vezes se perguntou como os botânicos ou os biólogos do século XIX puderam não ver que o que Mendel dizia era verdade. Acontece que Mendel falava de objetos, empregava métodos, situava-se num horizonte teórico estranho à biologia de sua época" (FOUCAULT, 2004, p. 34). Para Michel Foucault, Mendel estava certo, mas não estava no "verdadeiro" do discurso biológico de sua época. Seriam necessárias mudanças no campo da biologia para que ele finalmente “entrasse 'no verdadeiro' e suas proposições aparecessem, então, (em boa parte) exatas" (FOUCAULT, 2004, p. 35).

Mas não há, no presente texto, nenhuma intenção de afrontar o regime de verdade que paira sobre o teatro pernambucano, ao contrário, como historiador, estamos dando a ver este regime de verdade como fato. E oferecer essa 
visibilidade não é falsear a verdade desse regime, é apenas desnudar a verdade reduzindo-a ao formigamento de seu começo.

O esforço desta pesquisa é no sentido de mostrar que a verdade que paira sobre o teatro pernambucano não é "natureza", como nenhuma é. Do lugar teórico em que ela foi produzida não existe verdade natural, toda verdade é resultado de atos de criação linguística. Quando, por exemplo, Joel Pontes, Alexandre Figueirôa, Luís Maurício Carvalheira e Antonio Cadengue afirmaram que o Teatro de Amadores de Pernambuco (TAP) modernizou o teatro pernambucano, não estavam descobrindo a verdade auto evidente de um objeto já pleno de sentido e à espera de uma narrativa que o revelasse. Eles produziram um sentido. A linguagem produz sentido. Ela não se limita à descrição de uma ação, situação ou um estado de coisas, suas proposições também fazem com que algo aconteça. "Ao serem pronunciadas, essas proposições fazem com que algo se efetive, se realize" (SILVA, 2014, p. 92).

Assim, afirmar que o TAP modernizou o teatro pernambucano é atribuir um sentido à trajetória desse grupo teatral. E, nesse caso em particular, é também dizer a verdade estando "no verdadeiro" do discurso historiográfico e da memória consagrada não apenas do teatro pernambucano, mas também do "teatro brasileiro" (levando-se em conta a hierarquia que classifica como "nacional" o que é produzido nos estados mais "centrais" e "visíveis", como São Paulo e Rio de Janeiro, e como "regional" o que vem das demais regiões do país), já que essa afirmação, que singulariza o TAP, foi produzida em sintonia com a narrativa que levou Vestido de Noiva, peça de Nelson Rodrigues montada pelo grupo Comediantes em 1943, a ser considerada um ícone inaugural do modernismo teatral no cenário brasileiro. Ou seja, do ponto de vista conceitual, pode-se afirmar que o TAP fez em Pernambuco o equivalente àquilo que 0 Comediantes fez em termos de "teatro nacional". Vestido de Noiva e o Comediantes modernizaram o teatro brasileiro. Essa é a verdade. Ela é reconhecida dentro de um regime de verdade há muito consagrado e até hoje válido, o que não impede que outros estudiosos possam afirmar, por exemplo, que já existiam propostas modernas nos anos 1920 e 1930 (SIMÕES, 2010), 
constituindo enunciados que ainda não chegam a abalar a estabilidade do citado regime.

A verdade do teatro pernambucano, portanto, existe e está articulada às narrativas que informam a existência do teatro numa escala nacional. Essa verdade se fez história pelas narrativas de Joel Pontes, Alexandre Figueirôa, Luís Maurício Carvalheira, Antonio Cadengue e de outros pesquisadores que continuam produzindo em conformidade com as teses desses quatro importantes e, atualmente, inevitáveis estudiosos. Não estamos negando as verdades apontadas por eles. O que eles narram é a história do teatro pernambucano. A sociedade pernambucana reconhece isso e a maioria dos historiadores que se dedicam ao tema também reconhece isso. E não é objetivo deste trabalho contestar tal verdade.

Mas a verdade do teatro pernambucano tem uma história, como tudo o que é produzido pelo ser humano tem, e esse é o aspecto principal que queríamos enfatizar neste artigo. Queríamos, inspirados pelo lema de Píndaro (Chega a ser o que és!), tentar responder como o teatro pernambucano chegou a ser o que é, a partir de uma genealogia que nos apresenta a constituição de sua verdade.

\section{Referências}

ALBUQUERQUE JÚNIOR, Durval Muniz. A invenção do Nordeste e outras artes. 2. ed. Recife: FJN: Ed. Massangana; São Paulo: Cortez, 2001.

ASSMANN, Aleida. Espaços da recordação: formas e transformações da memória cultural. Campinas: Editora da Unicamp, 2011.

BOURDIEU, Pierre. A ilusão biográfica. In: AMADO, Janaína; FERREIRA, Marieta de Moraes. Usos e abusos da história oral. 8. ed. Rio de Janeiro: Editora FGV, 2006. p. 183-191. 
CADENGUE, Antonio Edson. TAP - sua cena \& sua sombra: o Teatro de Amadores de Pernambuco (1941-1991). Recife: Cepe: SESC Pernambuco, 2011a. v. 01.

CADENGUE, Antonio Edson. TAP - sua cena \& sua sombra: o Teatro de Amadores de Pernambuco (1941-1991). Recife: Cepe: SESC Pernambuco, 2011b. v. 02.

CANDAU, Joël. Memória e identidade. São Paulo: Contexto, 2012.

CARVALHEIRA, Luiz Maurício Britto. Por um teatro do povo e da terra: Hermilo Borba Filho e o Teatro do Estudante de Pernambuco. 2. ed. Recife: Cepe, 2011.

CAVALCANTE JÚNIOR, Idelmar Gomes. Inventário de uma memória consagrada: Benjamim Santos nos interstícios do teatro pernambucano (1960-1970). 2017. Tese (Doutorado em História Social) - Centro de Humanidades, Universidade Federal do Ceará, Fortaleza, 2017.

CERTEAU, Michel de. A invenção do cotidiano: 1. artes de fazer. 9. ed. Petrópolis: Vozes, 1994.

CERTEAU, Michel de. A escrita da história. 3. ed. Rio de Janeiro: Forense, 2011.

FIGUEIRÔA, Alexandre. O teatro em Pernambuco. Recife: Assembléia Legislativa do Estado de Pernambuco, 2005.

FOUCAULT, Michel. A ordem do discurso. São Paulo: Edições Loyola, 2004.

FOUCAULT, Michel. Microfísica do poder. 2. ed. Rio de Janeiro: Paz e Terra, 2015.

GUINSBURG, Jacó; PATRIOTA, Rosângela. Teatro brasileiro: ideias de uma história. São Paulo: Perspectiva, 2012.

KOSELLECK, Reinhart. Futuro passado: introdução a semântica dos tempos históricos. Rio de Janeiro: Contraponto: PUC-RJ, 2006.

OLIVEIRA, Reinaldo de. O palco da minha vida. Recife: Bagaço, 2013. 
PEREIRA, Nilo. Pernambucanidade. Recife: Secretaria de Turismo, Cultura e Esportes, 1983. v. 01.

PONTES, Joel. O teatro moderno em Pernambuco. Recife: Fundarpe, 1966.

SAID, Edward W. Orientalismo: o Oriente como invenção do Ocidente. São Paulo: Companhia das Letras, 2007.

SILVA, Tomaz Tadeu da. A produção social da identidade e da diferença. In: SILVA, Tomaz Tadeu da. Identidade e diferença: a perspectiva dos estudos culturais. Petrópolis: Vozes, 2014. p. 73-102.

SIMÕES, Giuliana. Veto ao modernismo no teatro brasileiro. São Paulo: Hucitec, 2010. 